\title{
Population status of the Madagascar Fish Eagle Haliaeetus vociferoides in 2005-2006
}

\author{
GILBERT RAZAFIMANJATO, THE SEING SAM, MARIUS \\ RAKOTONDRATSIMA, LILY-ARISON RENE DE ROLAND and \\ RUSSELL THORSTROM
}

\section{Summary}

Coastal and inland surveys for the endemic and "Critically Endangered" Madagascar Fish Eagle Haliaeetus vociferoides were conducted in western Madagascar from Antsiranana in the north to Manja in the south during the 2005 and 2006 breeding seasons (May-October). Surveys covered typical Madagascar Fish Eagle habitat: lakes, rivers, mangroves, estuaries, and marine islands within their known distribution. In total, 287 individuals were encountered, including 98 breeding pairs (196 individuals), 23 breeding trios (69 individuals), 15 single adults and seven immature birds. Of these 287 birds, 128 individuals (44.6\%) were observed on lakes; $116(40.4 \%)$ in coastal areas, consisting of $103(35.9 \%)$ in mangroves and $13(4.5 \%)$ in estuaries; $32(11.2 \%)$ on marine islands and $11(3.8 \%)$ on rivers. There was an increase between surveys in 1995 and this study in the number of Madagascar Fish Eagles counted, from 222 to 287, and in the number of pairs from 99 to 121. This study confirms that the Madagascar Fish Eagle population is still low due to human persecution (hunting, collection of eggs and nestlings), overfishing and habitat destruction. We recommend monitoring fish eagles annually at the higher concentration sites to evaluate human activities and conducting a population survey every five years throughout western and northern Madagascar.

\section{Résumé}

Le recensement le long de la côte et à l'intérieur de la terre continentale de l'Aigle Pêcheur de Madagascar Haliaeetus vociferoides a été mené dans la partie ouest de Madagascar depuis Antsiranana, au nord, jusqu'à Manja, au sud. Il a été effectué entre mai et octobre durant deux saisons de reproduction successive (2005 et 2006). Le dénombrement a couvert ses habitats caractéristiques entre autres les lacs, les mangroves, les estuaires et les îles marines à l'intérieur de son aire de distribution. Un total de 287 individus a été enregistré. Ils se répartissent en 98 couples normaux reproducteurs ( $n=196$ individus), 23 couples polyandres reproducteurs ( $n=69$ individus), 15 individus adultes solitaires et 7 individus immatures. Parmi ces individus, $44,6 \%(n=128$ individus) sont localisés dans l'écosystème lacustre ; 40,4\% $(n=116$ individus) dans les zones littorales dont $35,9 \%(n=103$ individus) fréquentent les mangroves et $4,5 \%(n=13$ individus) préfèrent les estuaires; $11,2 \%(n=32$ individus) dans les îles et îlot marins et 3,8\% ( $n=11$ individus) dans l'écosystème fluvial. Les nombres de l'aigle pêcheur et de couple recensés présentent respectivement un accroissement de 222 à 287 et de 99 à 121 entre le dernier comptage en 1995 et celui de la présente étude. Cette étude confirme que la taille de sa population reste faible à cause de la persécution humaine directe (chasse, collecte des œufs et des poussins), la surpêche et la dégradation de l'habitat. Le suivi annuel de l'Aigle Pêcheur de Madagascar dans les zones à forte concentration et le comptage systématique tout les cinq ans, couvrant les parties ouest et nord, est fortement recommandé. 


\section{Introduction}

The Madagascar Fish Eagle Haliaeetus vociferoides is the largest raptor in Madagascar and this island endemic is one of the rarest birds of prey in the world (Meyburg 1986). During the $19^{\text {th }}$ and most of the $2 \mathrm{O}^{\text {th }}$ centuries, this species was stated to be common along the north-west shoreline and up to $100 \mathrm{~km}$ inland (Owen 1833, Schlegel and Pollen 1868, Rabarisoa et al. 1997, Watson et al. 1999, Tingay 2000). Surveys from 1991 to 1995 counted a minimum of 222 adults at 105 sites with the breeding population estimated at 99 pairs (Rabarisoa et al. 1997).

It is important to periodically evaluate Madagascar Fish Eagle status and threats to its survival in order to propose further conservation measures when needed. It has been recognised that a conservation programme is needed for the Madagascar Fish Eagle to ensure its survival (Milon et al. 1973, Langrand and Meyburg 1989, Watson et al. 1993, 1996). Awareness and education campaigns among local communities in areas which have Madagascar Fish Eagles are one of the main components of the conservation effort. The Peregrine Fund's Madagascar Project has been implementing a sound conservation programme (Watson 1997a) which includes studies on breeding biology and behaviour, feeding ecology, ecological requirements, juvenile dispersal (Watson et al. 1993, Razafindramanana 1995, Berkelman 1997, Rafanomezantsoa 1997) and sibling rescue techniques as methods to increase the species's abundance (O'Daniel 1995, Watson et al. 1996, Watson 1997b).

We surveyed Madagascar Fish Eagle to determine its status, population size and trend, distribution, and current threats. The results of this study have important implications for conserving this highly threatened species.

\section{Methods}

The Madagascar Fish Eagle breeding season coincides with the southern hemisphere winter, beginning in late April to early May and ending in October, a period when rainfall and daytime temperatures are the lowest for the year (Watson et al. 1999). During this period, the species is fairly easy to detect at the nesting site due to its large size, appearance, habit of perching near the tops of trees and vocalisation.

Madagascar Fish Eagle surveys covered its known distribution in western Madagascar, from Antsiranana in the north to Manja in the south, totalling 2,299 km during the 2005 and 2006 breeding seasons (May-October) (Figure 1). Most effort was given to searching fish eagle habitat identified from previous surveys (Rabarisoa et al. 1997), topographic maps of Madagascar and Google Earth. Surveys were completed over 44 days from 12 June to 26 July 2005 and 48 days from 21 August to 7 October 2006. In 2005, surveys were concentrated in the northwestern coastal region from Baly Bay to Nosy Hara, and in 2006 we covered the western central coastal and inland areas from Tambohorano wetlands to Manja district. Madagascar Fish Eagle surveys focused on forests adjacent to lakes and rivers, coastal areas including islands and mangroves, river estuaries, and marine islands.

Coastal areas were surveyed from a twin-outboard powered fibreglass boat at a speed of $10 \mathrm{~km} / \mathrm{h}$ and a maximum distance of $100 \mathrm{~m}$ between observers and the coast. Special attention was paid to marine islands, estuaries, bays and mangroves where we spent 1-3 days depending on the size of the survey area. Marine surveys were conducted along the coast from Soalala to Nosy Hara, and at Belo-sur-Tsiribihina, Belo-sur-Mer and Manja. Coastal surveys were conducted from 12 June to 26 July 2005 and 2-4 September 2006, and marine islands from 22 June to I July 2005 at 20 previously known fish eagle sites. Several sections of the coast were not surveyed because they consist of unsuitable habitat for the fish eagle, for instance, the coastal area and islands between Besalampy and Maintirano, the areas between Belo-sur-Tsiribihina and Belo-sur-Mer, and between Belo-sur-Mer and Manja District (Figure 2). These areas have highly degraded mangroves or lack mangrove forests needed to support the Madagascar Fish Eagle.

Inland surveys along forested habitat adjacent to lakes, rivers and wetlands were conducted by $4 \times 4$ vehicles, local dugout canoes or on foot from Soalala and Manja to the south, and inland up to 


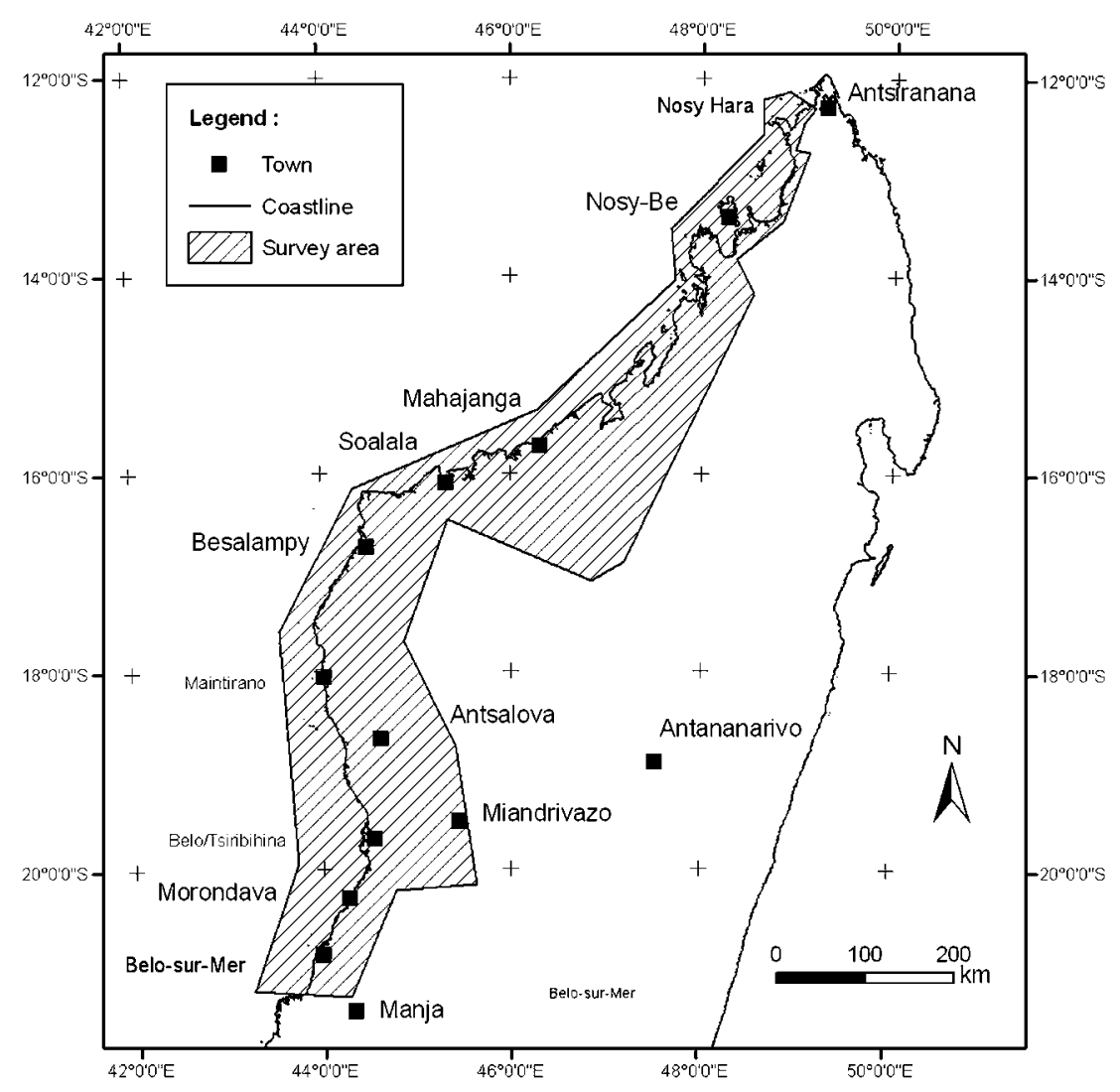

Figure 1. Map of western Madagascar showing the extent of Madagascar Fish Eagle surveys during 2005 and 2006.

$175 \mathrm{~km}$ from the coastline. All wetlands within the study area, i.e. known distribution range (Rabarisoa et al. 1997, Tingay 2005) were surveyed. Lakes and marshes from Analalava in the north to Manja district in the south (Table 1) were visited during 2005 and 2006. Nine districts Analalava, Marovoay, Mitsinjo, Soalala, Besalampy, Antsalova, Miandrivazo, Belo-sur-Tsiribihina, and Manja - were surveyed, along with Ankarafantsika National Park and Tambohorano wetlands. From August to September 2006, five rivers were surveyed; three (Soahany, Manambolo and Ampositsy) in Antsalova district, Tsiribihina River in Belo-sur-Tsiribihina district, and Mangoky River in Manja district.

All observations were made with $10 \mathrm{x} 50$ binoculars. Birds were recorded when they were observed visually or detected by vocalisations. We also searched for the presence of nests in order to find fish eagles associated with them.

Fishermen and local villagers were questioned for information on fish eagles in their area and all potential leads were followed (Rabarisoa et al. 1997). We also compiled data collected by national and international researchers from 2005 from different sites.

All fish eagles and nests encountered were recorded with a handheld GPS. ArcGIS 1o software was used to calculate the length of coastal surveys. The total area surveyed for Madagascar Fish Eagle was calculated by drawing polygons around all survey points.

Data recorded at the nest-site included date, time of day, time spent observing the nest-site, locality name and some or all of the following: number, age and sex (based on relative size of birds) of fish eagles present at the nest-site, distance between nests, behaviour, and number of young 


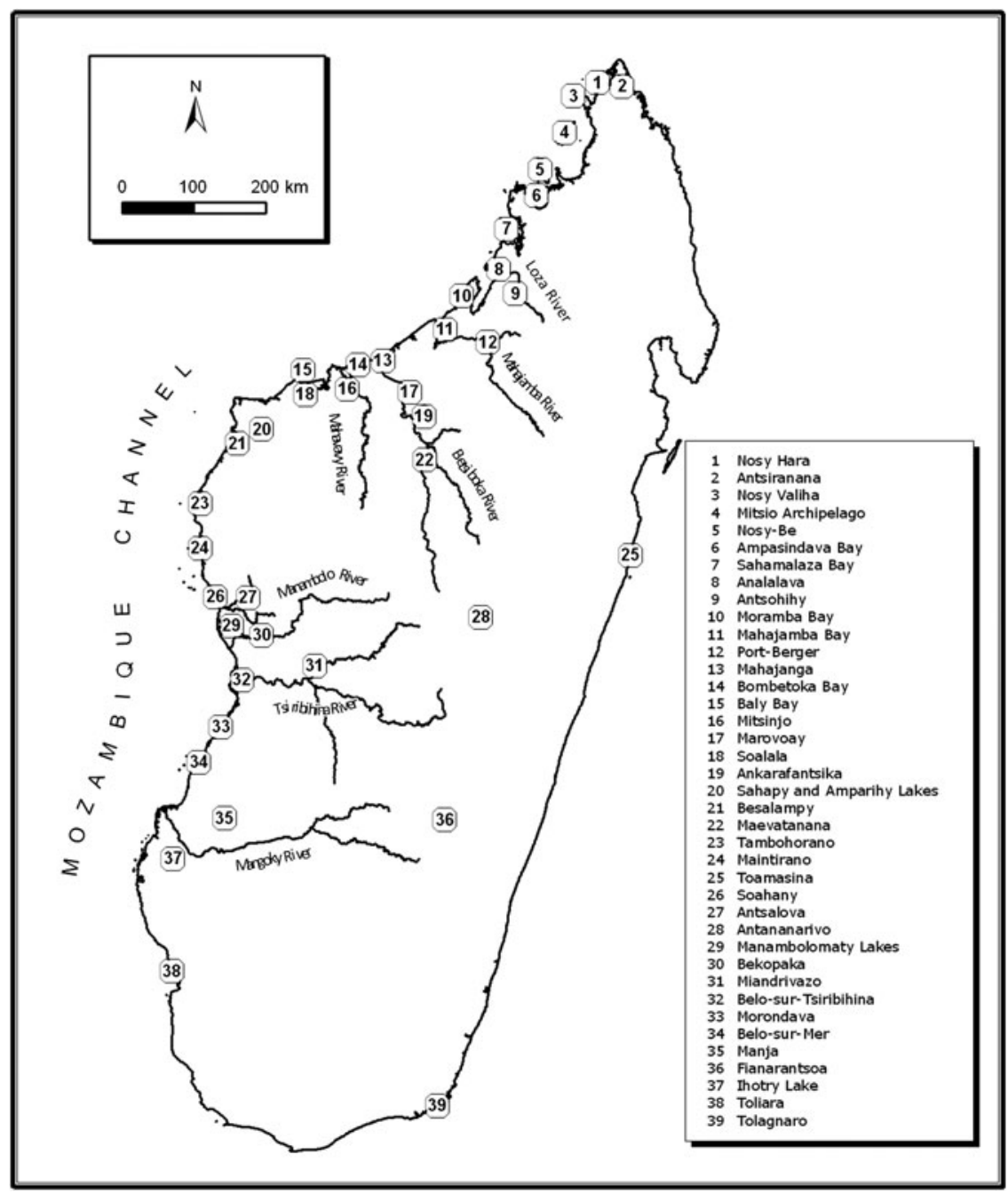

Figure 2. Map of Madagascar showing the sites mentioned in the text.

present. We observed at distances of 50-200 $\mathrm{m}$ from nest-sites. If a nest was visited by a fish eagle, it was recorded as occupied and the pair was considered to be potential breeders. If nest occupancy was not observed, we checked the nest contents from the ground using an extendable pole with a mirror attached or by climbing the nest tree (Rabarisoa et al. 1997). Nests were assumed to be occupied if they showed any signs of use, such as greenery lining the inside of the nest (Watson and Rabarisoa 1996), eggs or nestlings. Threats to Madagascar Fish Eagles were assessed during the surveys based on habitat characteristics and human activities.

\section{Results}

During the surveys, we learned of three vernacular Malagasy names for the Madagascar Fish Eagle, associated with the region and local Malagasy dialect: ankoay was very common in the 
western, southwestern and northwestern regions, and vorobe and vorohôlo (referring to its size and sensitivity to disturbance, respectively) were specific to the Miandrivazo district.

In total 287 individuals were recorded at 109 occupied breeding sites and 34 potential breeding sites. Of these, 280 were adults, four were sub-adults and three were juveniles. Of the 280 adults, 265 individuals were breeding, made up of 196 birds in pairs and 69 in breeding trios (two males and one female). Seventeen of the breeding trios (51 individuals) were observed in the Antsalova region and the other six ( 18 individuals) were recorded in north-western Madagascar, from Mahajamba Bay to Mitsio archipelago. Six important sites for fish eagles were identified: Belo-sur-Tsiribihina area, Antsalova area, Tambohorano wetland, Mahajamba and Moramba Bays, Sahamalaza Bay and Mitsio archipelago (Figure 3). Abandoned nests indicated a former breeding site.

\section{Habitat types where nests were found}

Lakes and marshes with surrounding forest had 44.6\% (128 individuals) of the documented fish eagles, coastal areas (mangroves and estuaries) had 40.4\% (116), marine islands held $11.2 \%$ (32), and rivers $3.8 \%$ (II). The numbers of Madagascar Fish Eagles recorded at each site within these four habitat types and the prevalent threats are listed in Tables $\mathrm{S}_{1}-\mathrm{S}_{4}$ in the online supplementary materials.

\section{Lakes and marshes}

These habitats held 66 potential fish eagle sites according to previous reports (Rabarisoa et al. 1997). Data from Analalava district were communicated by Andrianarimisa (pers. comm.), from Besalampy district by Rabenandrasana (pers. comm.) and from Mitsinjo district by Rabenandrasana and Sam (pers. comm.).

We recorded 128 fish eagles: 36 breeding pairs ( 72 birds), 18 breeding trios (54) and 2 single adults (Table 1; Tables $\mathrm{S}_{1}-\mathrm{S}_{4}$ in the online supplementary material). These 128 fish eagles were observed at 56 sites, of which 47 were nesting sites and nine potential breeding sites in the nine districts of western Madagascar. No Madagascar Fish Eagles were present at Anketrevo, Angodongodona and Besara lakes (Miandrivazo district), Antarotsakoa Lake (Manja district) and Ankarandrere Marsh (Manja district).

The main threats consist of habitat loss due to deforestation and transformation of wetlands into rice-fields, human persecution from hunting and collection of young from nests for pets or human consumption and for use in traditional medicine. Other threats to the species include human disturbance, such as fishermen's camps around lakes and cutting trees at nest-sites. Overfishing within Madagascar Fish Eagle foraging lakes causes food shortages to which it is especially sensitive during the breeding season. Finally, wildfires, invasion of water hyacinth Eichhornia sp., reed collecting, erosion and silting up also contribute to the habitat destruction that can affect the Madagascar Fish Eagle.

Table 1. Summary of Madagascar Fish Eagle numbers showing the number of breeding pairs, breeding trios and single birds recorded at lakes and marshes, rivers, coasts, and marine islands during the 2005 and 2006 surveys.

\begin{tabular}{lcccc}
\hline Habitat & Breeding pairs & Breeding trios & Single birds & Individuals \\
\hline Lakes and marshes & 36 & 18 & 2 & 128 \\
Rivers & 5 & 0 & 1 & 11 \\
Coasts & 49 & 2 & 12 & 116 \\
Marine islands & 8 & 3 & 7 & 32 \\
Total & 98 & 23 & 22 & \\
Number of individuals & 196 & 69 & 22 & 287 \\
\hline
\end{tabular}




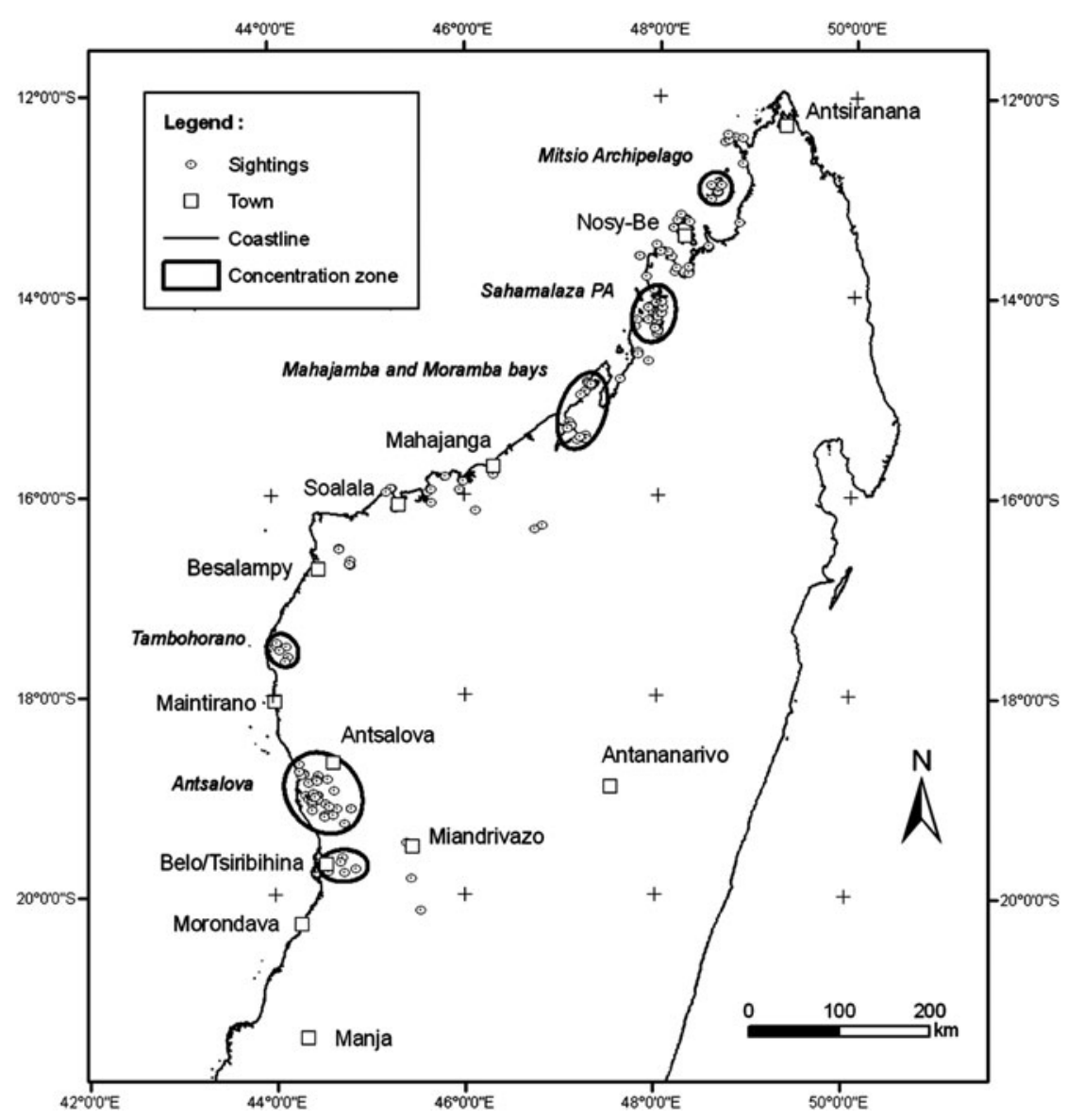

Figure 3. Map of breeding pairs, territorial pairs and individuals of Madagascar Fish Eagles during 2005 and 2006. Circled areas show the higher concentration sites.

\section{Rivers}

Eight potential fish eagle sites were surveyed. Five breeding pairs and one single adult were recorded on rivers in Antsalova district. Four breeding pairs were observed along the Soahany River in the north-west and one pair was present on the Manambolo River in the south, but we did not find the nest. One single adult was seen on the Ampositsy River. No Madagascar Fish Eagles were recorded on the Tsiribihina and Mangoky Rivers (Table S2). Most of the rivers were silted up because tree cutting had removed structural support along the banks.

\section{Bays and estuaries}

We surveyed 75 fish eagle sites along the south-western, western and north-western coasts of Madagascar (from Manja district in the south to Befotaka Bay in the north). Of these 75 sites, 48 contained breeding pairs and 24 were recorded as potential breeding. Three sites in the south-west from Belo-sur-Tsiribihina to Manja districts were not occupied by fish eagles (Table $\mathrm{S}_{3}$ ).

We recorded 116 fish eagles, made up of 49 breeding pairs, two breeding trios, nine single adults, one sub-adult and two juveniles. Of the 116 birds, 103 were associated with bays and 
13 with estuaries. Three pairs were observed without nests. All observed nests were built in tanga trees which are the tallest in mangrove habitat. There are two species: Rhizophora mucronata ('tangandahy') and Ceriops tagal ('tangambavy').

The main threats in the coastal environment are overfishing and presence of fishermen's camps, harvesting of mangrove forests, harvesting of crabs, shrimp farm developments, collecting of fish eagle eggs and young, shooting and trapping of adult fish eagles, and development of tourism infrastructures on the islands.

\section{Marine Islands}

We encountered 32 fish eagles (11.2\% of the total recorded during the two years). We recorded II breeding sites (eight breeding pairs and three breeding trios), eight potential breeding sites (seven with a single bird - three adults, three sub-adults and one juvenile) and one site with an abandoned nest and no pair present. We did not record any fish eagles on Nosy Hara (Table $\mathrm{S}_{4}$ ).

The main habitats on these islands were rocks, mangroves and western dry forests. One breeding trio was observed nesting on a rock outcrop. We observed no threats on these marine islands compared to bays and estuaries.

\section{Discussion}

\section{Limits of distribution}

Recent reports identified the Antsalova and Belo-sur-Tsiribihina regions and the north-west coastal area from Mahajamba bay to Nosy Hara as having the highest concentrations of Madagascar Fish Eagles in the country (Rabarisoa et al. 1997, Tingay 2005). During the current surveys, six areas stood out as having an important population and nesting pairs of fish eagles: Belo-sur-Tsiribihina, Antsalova, Tambohorano wetland, Mahajamba and Moramba Bays, Sahamalaza Bay and Mitsio Archipelago (Figure 3). The highest population of fish eagles was at Sahamalaza Marine National Park with 14 breeding pairs/trios (29 individuals), followed by Manambolomaty Lakes complex with 12 pairs/trios (34 individuals).

Sahamalaza protected area had two more pairs but five fewer individuals than the Manambolomaty Lakes complex because the majority of the nesting birds at Manambolomaty formed breeding trios. The second male in the trio is believed to be a helper at the nest (Tingay 2005). It has been assumed that this breeding strategy developed because the fish eagles are at maximum carrying capacity here, based on a home range of $200 \mathrm{ha}$, while the surface area of the three lakes totals 1,181 ha (Razafindramanana 1995) and single birds cannot occupy a territory, so they become a helper for the mated pair (Oring 1986, Newton 1998). These trios are frequently observed in Antsalova district too.

The six concentration zones of Madagascar Fish Eagles could be explained by differences in conservation effort and habitat disturbance at the sites. Firstly, in three zones, Belo-sur-Tsiribihina, Manambolomaty area at Antsalova and Mandrozo wetland at Tambohorano, local traditional culture contributes to the conservation of the Madagascar Fish Eagle, as traditional rules regulate fishing activities at the lakes and the surrounding forest (Rabearivony et al. 2008). Secondly, the existence of the community-based natural resource management system and the protected area at Manambolomaty at Antsalova, Mandrozo at Tambohorano and Sahamalaza costal and marine protected area aim at conserving the local and unique biodiversity (ANGAP 2001, Rabearivony et al. 2008, The Peregrine Fund 2009). Mahajamba and Moramba bays consist of aquaculture zones where access is limited to prevent disturbance to shrimp farms. The surrounding mangroves are also left undisturbed to provide long-term ecological protection for the farm and may explain why there is a concentration of birds here and on the Mitsio archipelago, where hotel complexes have an interest in keeping the natural habitat of the islands in a healthy condition. 
The Antsalova district contains an important breeding population of fish eagles, and it averaged a loss of two nest trees per year between 1992 and 1997 (Rabarisoa 1999). The loss of nest trees ceased in 2001 when two local community associations at the Manambolomaty Lakes complex began a nationally recognised resource management programme allowing them to control their natural resources independently of the Malagasy government (Watson et al. 2007, Rabearivony et al. 2008).

Madagascar Fish Eagle distribution has been described as along the west and north-west coast between Morombe in the south and Antsiranana in the north (Langrand 1987, Langrand and Meyburg 1989, Rabarisoa et al. 1997, Rabarisoa 1999). One breeding pair of Madagascar Fish Eagle was recorded at Sandoz rocky island ( $\left.12^{\circ} 14^{\prime} 46.00^{\prime \prime} \mathrm{S}, 49^{\circ} \mathrm{Oo}{ }^{\prime} 26.39^{\prime \prime} \mathrm{E}\right)$ in Nosy Hara Marine National Park in 2010 (Jaomanana pers. comm.).

One ringed adult was observed flying above the mangroves around Belavenoke village, south Morombe, in September 2011, extending the known range. Conservation efforts since 2003 may be the cause of this extension.

During coastal surveys in Manja district, Rabarisoa (1999) reported one pair of fish eagles on the Amboliboly coast in mangroves, but we didn't find any during our surveys at this site. Furthermore, locals under 30 years of age who live at Andranopasy village, $2 \mathrm{~km}$ north of the Amboliboly, were not able to describe the Madagascar Fish Eagle, suggesting they have been absent for several decades. Only men older than 30 years of age who had fished in the area as young children were able to identify the species. Apparently, its disappearance from this site is related to over-exploitation of the mangrove trees which took place approximately 25 years ago as reported by the local community. Asity Madagascar was reported to have observed one adult at Ankorohoro Lake $\left(21^{\circ} 52^{\prime} 51.7^{\prime \prime} \mathrm{S}\right.$, $44^{\circ} \mathrm{O}^{\prime} 44.4^{\prime \prime} \mathrm{E}$ ) (Rabarisoa pers. comm.) in March 2005. However, monitoring results from 2006 confirmed that Madagascar Fish Eagles were not present at this site because of habitat disturbance.

Madagascar Fish Eagles have been reported to occupy suitable habitat from sea level to 1,200 $\mathrm{m}$ on lakes and rivers up to 90-100 km inland, mangroves, estuaries, and rocky islands near the coast (Langrand 1990, Rabarisoa et al. 1997). Our study showed that the altitudinal limit of Madagascar Fish Eagles was much lower, below $650 \mathrm{~m}$. At the Montagne d'Ambre National Park (850-1,475m), the last records of Madagascar Fish Eagles were in 1999 according to the Park director and the conservation research officer (Rabenatoandro Solofo Harison and Saindou pers. comm.). Consequently, Madagascar Fish Eagles do not occur in mid-altitude habitat (700-1,500 m) or above. We also documented a maximum distance of $140 \mathrm{~km}$ inland; in 2010 one individual was observed flying around Ambalanjanakomby ( $\left.16^{\circ} 4^{\prime} 2^{\prime} \mathrm{O} .19^{\prime \prime} \mathrm{S}, 47^{\circ} 04^{\prime} 18.48^{\prime \prime} \mathrm{E}\right)$, Maevatanana which is located about $140 \mathrm{~km}$ from the coast.

\section{Total population}

The Madagascar Fish Eagle population was estimated at 1o pairs in the 1970s (Collar and Stuart 1985) and was considered "Endangered" with a global population of 40-50 pairs in the 1980s (Collar and Stuart 1985, Collar et al. 1987, Langrand and Meyburg 1989). Surveys in western Madagascar from 1980 to 1985 recorded 96 individuals including 40 breeding pairs (Langrand and Meyburg 1989). Consequently, it was classified as one of the most critically endangered raptors in the world (Dee 1986).

Rabarisoa et al. (1997) estimated the total population of Madagascar Fish Eagles in 1991-1995 to be 222 individuals, made up of 63 breeding pairs with nests, 36 probable pairs and 24 additional adults, comprising five single adults, four adults soaring together and 15 "helpers" at nests. Furthermore, these authors believed more pairs of Madagascar Fish Eagles may inhabit regions they did not survey and that the total population was higher, perhaps in the region of 120 pairs. Our survey appeared to confirm this. During our surveys in 2005 and 2006 we recorded 287 individuals, $29 \%$ more (65 individuals). We cannot rule out an increase in the breeding population, but we believe that our greater search effort, covering more of the suitable habitat and the experience of the team were the main factors for the higher number of Madagascar Fish Eagles counted. However, we still believe the Madagascar Fish Eagles is the most 
threatened bird in Madagascar due to the intensity of forest and wetland habitat degradation the last two decades.

Since 1992, systematic annual monitoring consisting of three surveys has been conducted during the egg-laying, hatching and fledgling periods by The Peregrine Fund's Madagascar Project in Antsalova district, and a population survey is carried out every five years at nearly all known fish eagle territorial sites and habitat as reported in this paper. Twenty-seven breeding pairs and three probable pairs were located from surveys in 1995 in the wetlands of the Antsalova region (Rabarisoa et al. 1997). In 2000, in the same site, Tingay (2005) encountered 69 individuals. But in 2006, we counted only 25 breeding pairs/trios comprising 66 individuals. One of the reasons for this difference is confusion over the administrative limits of these districts. Rabarisoa et al. (1997) and Tingay (2005) considered the three sites of Ambondrobe, Maromahia and Bejijo in the Antsalova district during their studies, instead of Belo-sur Tsiribihina district.

Elsewhere, Rabarisoa et al. (1997) recorded 12 breeding pairs, four probable pairs and three immatures at 16 sites during the 1992-1995 surveys in Belo-sur-Tsiribihina region. This study recorded 19 individuals comprising eight breeding pairs and one breeding trio at 11 different sites. We believe this reduction in the number of fish eagles and pairs was due to the increase in human activities and pressures. In Miandrivazo district, several pairs which existed in 1991 were not observed during surveys in 2006. Also, some lakes were being managed by local community associations.

\section{Evidence for population change}

This study shows that the Madagascar Fish Eagle population size exceeds the threshold of 250 mature individuals for "Critically Endangered" under criterion C according to the IUCN categories and criteria (IUCN 2001). However, surveys conducted by The Peregrine Fund in 2010 in Besalampy, Belo-sur-Tsiribihina and Ankavandra show the population is decreasing slowly and we suggest that the status of the species should not be changed to Endangered (EN), until another countrywide population estimate has been completed to determine how the population is faring.

\section{Threats}

Madagascar Fish Eagles were once described as common along the north-west coast of Madagascar, but Langrand and Meyburg (1989) reported the population had drastically declined during the past few decades. Direct persecution by taking nestlings for food (Watson et al. 1993, 1999, Watson and Rabarisoa 1996), the deliberate destruction of nests and young (Thiollay and Meyburg 1981, Rabarisoa et al. 1997), shooting and trapping of adults (Langrand and Meyburg 1984), the use of eagle body parts in traditional medicine (Razandrizanakanirina and Kalavaha 1997, Rabarisoa et al. 1997) and the capture of eagles for pets (Watson 1997c) have all been cited as the greatest threats to Madagascar Fish Eagles.

Madagascar Fish Eagle nest-sites are typically in mature trees bordering rivers and lakes, in estuaries and mangroves and in littoral forest along the coast. In addition, nests are built directly on top of rocky outcrops. These nest-sites were predominantly found on islands along the coast between Mahajanga and Nosy Hara (Rabarisoa et al. 1997, 2003, Tingay 2005) but most of the pairs we found nesting on rocky islands were in Moramba Bay. Only one breeding trio was found nesting on a rocky island at Nosy Tsiankazo, near Anorontany Peninsula. Berkelman et al. (2002) found nest-site selection in some areas was dependent on a sufficient number of foraging perches as well as suitably-sized nest trees. In the coastal zone, our surveys found that Madagascar Fish Eagles built their nests in only two mangrove species: Rhizophora mucronata and Ceriops tagal. This preference was due to these trees being taller and stronger limbed and able to support fish eagle nests. These tree species are also used by local people and fishermen for fences, houses, huts, 
firewood and drying racks (Razafimanjato pers. obs.). Unsustainable management of these trees could threaten nesting habitat for Madagascar Fish Eagles in mangroves.

In conclusion, the areas we surveyed covered more than 90\% (using ArcGIS 10 software) of the habitat and distribution of Madagascar Fish Eagles and there may be a few more pairs that we were unable to survey or detect. There is no genetic isolation or disjunct breeding subpopulations of the species as suggested by Rabarisoa et al. (1997), but it has been determined that the population has been naturally limited and stable probably due to the species's life-history traits of low productivity, low density distribution and longevity (Tingay 2005). Madagascar Fish Eagles have maintained a small but stable effective population size with extremely low genetic diversity for thousands of years compared to other Haliaeetus species (Johnson et al. 2009). This study showed that the population size was higher than previously reported. Conservation efforts should focus on protecting and maintaining fish eagle habitat, with a high priority given to the six breeding concentration sites identified in this study, and on preventing and reducing human persecution by increasing human awareness for this unique species. We recommend annual monitoring and public awareness raising at the high concentration sites in order to inform local communities and reduce human pressure, followed by systematic monitoring every three years throughout their historic distribution.

\section{Supplementary Material}

The supplementary materials for this article can be found at journals.cambridge.org/bci

\section{Acknowledgements}

We thank the Ministry of Environment, Water, Forest and Tourism (MEEFT), and Madagascar National Parks (ex-ANGAP) for their collaboration with The Peregrine Fund's Madagascar Project and their role in conservation in Madagascar. We would like to thank Shanta Barley from Blue Ventures for her information about Madagascar Fish Eagle distribution and we extend our special thanks to our field technician staff, and especially Kalavah Loukman and Norbert Rajaonarivelo for assisting in the surveys. Thanks also to Aristide Andrianarimisa and Marc Rabenandrasana for providing information about the species. We thank also Phil Atkinson and other reviewers for their valuable comments that improved the manuscript. Madagascar Fish Eagle surveys were supported by The Peregrine Fund and the Liz Claiborne and Art Ortenberg Foundation.

\section{References}

ANGAP (2001) Madagascar Protected Area management system plan 2001-2006. Antananarivo: Ministère de l'Environnement, des Eaux et Forêts.

Berkelman, J. (1997) Habitat requirements and foraging ecology of the Madagascar Fish Eagle. PhD Thesis. Blacksburg, VA: Virginia Polytechnic Institute and State University.

Berkelman, J., Fraser, J. D. and Watson, R. T. (2002) Nesting and perching habitat use of the Madagascar Fish Eagle. J. Raptor Res. 36: $287-293$.

Collar, N. J. and Stuart, S. N. (1985) Threatened birds of Africa and related islands: The ICBP/IUCN Red Data Book. Part I. Third edition. Cambridge, UK: ICBP.
Collar, N. J., Dee, T. J. and Goriup, P. D. (1987) La conservation de la nature à Madagascar: perspective du CIPO. Occasional Papers IUCN/SCC 2: 97-108.

Dee, T. J. (1986) The endemic birds of Madagascar Cambridge, UK: ICBP.

IUCN (2001) Red List categories and criteria Version 3.1. Gland, Switzerland: IUCN.

Johnson, J. A., Tingay, R. E., Culver, M., Hailer, F., Clarke, M. L. and Mindell, D. P. (2009) Long-term survival despite low genetic diversity in the criticallyendangered Madagascar fish-eagle. Mol. Ecol. 18: 54-63.

Langrand, O. (1987) Distribution, status and conservation of the Madagascar Fish Eagle 
Haliaeetus vociferoides Desmurs 1845. Biol. Conserv. 42: 73-77.

Langrand, O. (1990) Guide to the birds of Madagascar. New Haven, CT: Yale Univ. Press.

Langrand, O. and Meyburg, B.-U. (1984) Birds of prey and owls in Madagascar: their distribution, status and conservation. Pp. $3^{-13}$ in J. M. Mendelsohn and C. W Sapsford, eds. Proceedings of the III World Conference on Birds of Prey and Owls, 22-27 March 1987, Eilat, Israel. London, UK: World Working Group on Birds of Prey and Owls.

Langrand, O. and Meyburg, B.-U. (1989) Range, status and biology of the Madagascar Sea Eagle, Haliaeetus vociferoides. Pp. $269-277$ in B.-U. Meyburg and R. D. Chancellor, eds. Raptors in the modern world. Berlin, Germany: World Working Group on Birds of Prey.

Meyburg, B.-U. (1986) Threatened and Nearthreatened diurnal birds of prey of the world. Birds of Prey Bull. 3: 1-12.

Milon, P., Petter, J.-J. and Randrianasolo, G. (1973) Faune de Madagascar, 35. Oiseaux. Tananarive and Paris: ORSTOM and CRNS.

Newton, I. (1998) Population limitation in Birds. London, UK: Academic Press.

O'Daniel, D. (1995) Raising Cain ... and Abel. Living Bird 14: 30-35.

Oring, L. W. (1986) Avian polyandry. Pp. 309-351 in R. J. Johnston, ed. Current ornithology Vol. 3. New York, USA: Plenum Press.

Owen, W. F. W. (1833) Narrative of voyages to explore the shores of Africa, Arabia and Madagascar. Vol. II. London: Richard Bentley.

Rabarisoa, R. (1999) Nouveaux éléments sur la distribution du Pygargue de Madagascar Haliaeetus vociferoides dans la région du sud-ouest de Madagascar. Pp 110-114 in A. Andrianarimisa, ed. Projet de conservation des zones humides de Madagascar. Conservation de la biodiversité, vers une gestion communautaire $d u$ complexe lacustre de la forêt de Tsimembo. Rapport d'avancement $V, 1997$ \& 1998. Antananarivo, Madagascar: The Peregrine Fund's Madagascar Project.
Rabarisoa, R., Rafanomezantsoa, S. A. and Watson, R. T. (2003) Falconiformes: Haliaeetus vociferoides, Madagascar Fish Eagle, Ankoay. Pp. 1085-1087in S. M. Goodman and J. P. Benstead, eds. The natural history of Madagascar. Chicago, USA and London, UK: Chicago University Press.

Rabarisoa, R., Watson, R. T, Thorstrom, R. and Berkelman, J. (1997) Status of the Madagascar Fish Eagle Haliaeetus vociferoides in 1995. Ostrich 68: 8-12.

Rabearivony, J., Fanameha, E., Mampiandra, J. and Thorstrom, R. (2008) Taboos and social contracts: Tools for ecosystem management - lessons from the Manambolomaty Lakes RAMSAR site, western Madagascar. Madagascar Conserv. Devel. 3: 7-16.

Rafanomezantsoa, S. (1997) Behavior and natal dispersal of fledgling Madagascar Fish Eagles. Pp. 403-412 in R. T. Watson, ed. Madagascar wetlands conservation project: Developing community-based conservation in a proposed wetland Biosphere Reserve in Madagascar. Progress Report III, 19951996. Boise, USA: The Peregrine Fund.

Razafindramanana, S. (1995) Contribution à l'étude de la biologie de Haliaeetus vociferoides, Desmurs 1845 (Pygargue de Madagascar): reproduction et domaine vital. Mémoire de Diplôme d'Etudes Approfondies de Sciences Biologiques Appliqués. Antananarivo, Madagascar: Université d'Antananarivo.

Razandrizanakanirina, D. and Kalavaha, L. (1997) Community-based wetland conservation project: 1996 Mission notes. Pp. 105-120 in R. T. Watson, ed. Madagascar wetlands conservation project: Developing community-based conservation in a proposed wetland Biosphere Reserve in Madagascar. Progress Report III, 19951996. Boise, USA: The Peregrine Fund.

Schlegel, H. and Pollen, F. P. L. (1868) Recherches sur la faune de Madagascar et des ses dépendances, d'après les découvertes de François P. L. Pollen et D. C. van Dam $2^{\text {ème }}$ partie. Mammifères et oiseaux. Leyden

The Peregrine Fund (2009) Plan d'aménagement et de gestion de la nouvelle aire protégée de Mandrozo. Boise, USA: The Peregrine Fund. 
Thiollay, J. M, and Meyburg, B.-U. (1981) Remarques sur l'organisation d'un peuplement insulaire de rapaces: Madagascar. Alauda 49: 216-226.

Tingay, R. E. (2000) Sex, lies and dominance: Paternity and behaviour of extra-pair Madagascar Fish Eagle Haliaeetus vociferoides. MSc thesis. Nottingham, UK: University of Nottingham.

Tingay, R. E. (2005) Historical distribution, contemporary status and cooperative breeding in the Madagascar Fish Eagle: Implications for conservation. $\mathrm{PhD}$ thesis. Nottingham, UK: University of Nottingham.

Watson, R. T. (1997a) Madagascar Fish Eagle conservation. Pp. 45-50 in R. T. Watson, ed. Madagascar wetlands conservation project: Developing community-based conservation in a proposed wetland Biosphere Reserve in Madagascar. Progress Report III, 1995-1996. Boise, USA: The Peregrine Fund.

Watson, R. T. (1997b) Madagascar Fish Eagle sibling rescue in 1995 and 1996. Pp. 283288 in R. T. Watson, ed. Madagascar wetlands conservation project: Developing community-based conservation in a proposed wetland Biosphere Reserve in Madagascar. Progress Report III, 19951996. Boise, USA: The Peregrine Fund.

Watson, R. T. (1997c) Captive breeding and display aviary for Madagascar Fish Eagles in Parc Tsimbazaza: a multiple conservation opportunity. Pp. 413-416 in R. T. Watson, ed. Developing community-based conservation in a proposed wetland Biosphere Reserve in Madagascar. Progress report III, 1995-1996. Boise, USA: The Peregrine Fund.

Watson, R. T. and Rabarisoa, R. (1996) Sakalava fishermen and Madagascar Fish Eagles: enhancing traditional conservation rules to control resource abuse that threatens a key breeding area for an endangered eagle. Proc. $9^{\text {th }}$ Pan-Afr. Orn. Congr.

Watson, R. T., Berkelman, J., Lewis, R. and Razafindramanana, S. (1993) Conservation studies on the Madagascar Fish Eagle Haliaeetus vociferoides. Proc. Pan-Afr. Orn. Congr. 8: 192-196.

Watson, R. T., Razafindramanana, S., Thorstrom, R. and Rafanomezantsoa, S. A. (1999) Breeding biology, extra-pair birds, productivity, siblicide and conservation of the Madagascar Fish Eagle. Ostrich 70: 105-111.

Watson, R. T., Rene de Roland, L.-A., Rabearivony, J. and Thorstrom, R. (2007) Community-based wetland conservation protects endangered species in Madagascar: lessons from science and conservation. Banwa 4: 81-95.

Watson, R. T., Thomsett, S., O'Daniel, D. and Lewis, R. (1996) Breeding, growth, development, and management of the Madagascar Fish Eagle (Haliaeetus vociferoides). J. Raptor. Res. 30: 21-27.

GILBERT RAZAFIMANJATO*, THE SEING SAM, MARIUS RAKOTONDRATSIMA, LILY-ARISON RENE DE ROLAND

The Peregrine Fund's Madagascar Project, B.P. 4113, Antananarivo (101), Madagascar.

\section{RUSSELL THORSTROM}

The Peregrine Fund, 5668 West Flying Hawk Lane, Boise, ID 83709, USA.

*Author for correspondence; email: rmanjato@yahoo.fr

Received 20 June 2011; revision accepted 25 September 2012; Published online 28 March 2013 